\title{
Gaveøkonomi - en vej til ny velfærdsværdi
}

\author{
Af Niels Thygesen *)
}

\begin{abstract}
Resumé
Som forskeren i offentlig ledelse, Mark Moore, udtrykker det: "Offentlige ledere er hverken bogholdere eller martyrer. I stedet er de bestilt af samfundet til at eftersøge velfærdsværdi ('public value')". I det lys bidrager artiklen med et teoretisk-illustrativt bud på, hvordan en ny og lovende gaveøkonomi kan bidrage væsentligt til vores velfærd i betydningen at 'færdes vel'. Gaveøkonomi er en økonomisk udveksling, der skaber velfærdsværdi gennem relationer, dvs. hvor hver part får adgang til det, som andre giver (gaver), ved selv af give (gengave). Som sådan udgør gaveøkonomien et andet medie for udveksling end penge, som skaber velfærdsværdi gennem adskillelse. Budskabet er, at vi ikke blot skal være opmærksom på, at pengeøkonomiens adskillelsesmaskine faktisk kan stå i vejen for velfærd. Vi skal også være opmærksom på, at gaveøkonomien kan skabe velfærdsværdi, som er pengeøkonomien overlegen.
\end{abstract}

\section{Emneord}

Velfærd, ledelse, gaveøkonomi, pengeøkonomi, socio-økonomi systemteori.

*) Niels Thygesen, Ph.d. og lektor på Institut for Ledelse, Politik og Filosofi (LPF) på Copenhagen Business School (CBS). Niels Thygesens forskningsområde er velfærdsledelse. 


\section{A. Introduktion}

"Staten er nødt til at gøre menneskeliv op i kroner og øre". Sådan lød overskriften i en opinionsartikel i Altinget d. 2 juni, 2020, og som udfoldede pandemiens pris. Citatet viser, at vi befinder os i et pengeøkonomisk rationale, hvor selv menneskeliv bliver gjort op i kroner og øre. Citatet viser også, hvordan det pengeøkonomiske rationale er overgribende, når det er staten, der foretager en opgørelse på alles vegne, og samtidigt indgribende, når det gælder hvert enkelte menneskeliv.

Artiklens første hovedpointe består i, at det dominerende pengeøkonomiske rationale som ligger til grund for udformningen af vores velfærd i velfærdssamfundet, baserer sig på adskillelse. Det ser vi fx, når velfærden opgøres økonomisk og som led heri ofte prissættes i form af enkeltydelser.

Mens pengeøkonomien har udmærket sig ift. at prioritere, effektivisere og evaluere velfærden, så står pengeøkonomien også i vejen for velfærd - i betydningen at 'færdes vel'.

Opgaven består derfor $\mathrm{i}$ at iagttage pengeøkonomiens iagttagelser af, hvad der tæller som velfærdsværdi, for det giver os en unik mulighed for at træde ud af den pengeøkonomiske adskillelsesmaskine og stille spørgsmålstegn ved, om disse iagttager er de eneste økonomiske iagttagelser, der findes samt hvorvidt og hvordan andre økonomier stiller andre iagttagelser til rådighed af velfærd og værdi.

Artiklens anden hovedpointe er, at der findes et økonomisk alternativ til pengeøkonomien, hvorved velfærden i samfundet kan iagttages og opbygges. Alternativet hedder gaveøkonomi. Denne økonomi er ikke blot interessant, fordi det er en økonomi, hvis udvekslinger er baseret på relationer, frem for adskillelse, men fordi dens velfærdspotentiale kan overgå pengeøkonomiens.

Et billede på artiklens første budskab er personaen Peter, som Mandag Morgen formidlede d. 22 januar, 2018. Han er et eksempel på, hvordan den velfærdsmaskine vi har opbygget, kan stå i vejen for velfærd. 


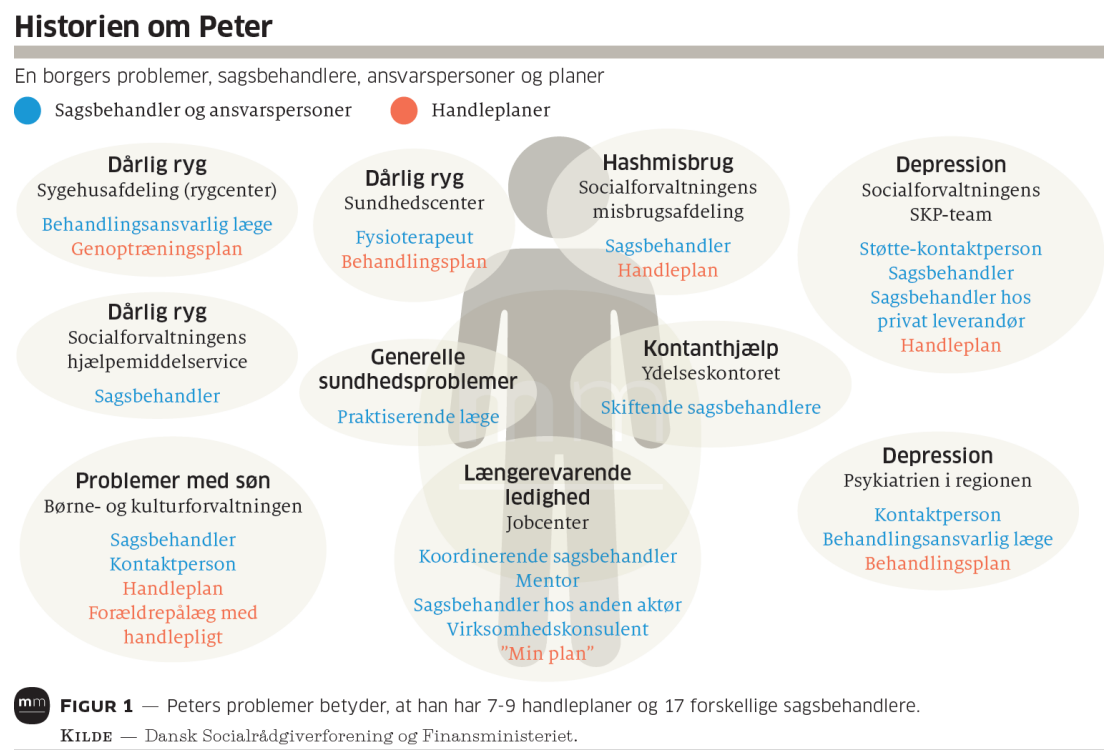

Figur 1: Peters problemer betyder, at han har 7-9 handleplaner og 17 forskellige sagsbehandlere.

(Kilde: Dansk Socialrådgiverforening og Finansministeriet.)

Set fra et økonomisk perspektiv er Peter et billede på den nuværende pengeøkonomiske organisering af velfærden og dens adskillelser samt en opfordring til at gentænke måden vi skaber velfærdsværdi.

Peter er fast kunde på jobcentret. Organiseringen sørger for, at Peter bliver savet over via adskilte budgetposter. Hver budgetpost finansierer hver sin ydelse - én for hver af de udfordringer, som Peter har. Der er udarbejdet otte handleplaner for Peter. De dækker hans fysiske, psykiske, familieog jobmæssige problemer. Peter har i den forbindelse 17 forskellige sagsbehandlere.

Peter er ikke alene. En analyse foretaget af Deloitte for Finansministeriet viser, at sagsbehandlere i kommunerne hvert år udarbejder op mod 950.000 handleplaner. ${ }^{i i}$ Mange af handleplanerne er nødvendige, men situationen syntes også uholdbar. Vi risikerer at spilde ressourcerne gennem ukoordinerede parallelindsatser og dobbeltarbejde, der forbruger Peters engagement på et niveau, der faktisk kan forhindre, at han færdes vel.

At Peter på linje med så mange andre borgere bliver savet over, skyldes ikke dårlige politikere eller ledere. Det skyldes, at der ikke bliver stillet spørgsmålstegn ved den adskillelsesmaskine, der består i, at velfærd enten sættes lig den samlede sum af enkelte og opdelte ydelser eller prioriteres, effektiviseres og evalueres, som om den var det.

Artiklens andet hovedbudskab, bliver understreget i Randers Kommune og i Thy nationalpark. De er begge eksempler på, at der findes et økonomisk alternativ til pengeøkonomien, som er 
gaveøkonomi, og at dens velfærdspotentiale kan overgå pengeøkonomiens. Som artiklen uddyber senere, så består gaveøkonomien i forpligtelsen til at give, forpligtelsen til at modtage og forpligtelsen til gensidighed. Men indledningsvist er det nok at konstatere, at på de udvalgte indsatsområder i Randers og Thy er der ingen, der drømmer om at save noget over.

"Lån et lokale og gør de ældre glade". Sådan lyder det fra seks ældrecentre i Randers Kommune, der giver foreninger mulighed for at booke de tomme møde-, og forsamlingslokaler i weekenden og i aftentimerne ${ }^{i i i}$. Det er gratis for foreningerne at låne lokalerne (gave). Men det er ofte en betingelse, at de aktiviteter, der foregår, skal "bidrage til centrets liv" - for eksempel ved at inddrage beboerne i aktiviteterne (gengave). På den måde får hver part får adgang til det, som de andre giver, ved selv af give, hvilket har større værdi for alle, end hvis de lod være. Her er nogle af de aktiviteter, som er skabt gennem gaveøkonomien, og som har værdi for alle parter:

1) Lungeforeningen Danmark og aftenskolerne har nu to faste lungekor for KOL-patienter og kræftsyge. 2) Babysalmesang er nu er fast aktivitet på Åbakken i Øster Tørslev, på Borupvænget og i Kollektivhuset i Randers C til glæde for både ældre og yngre. 3) Yoga- og pilateshold har fået deres faste gang på en række ældrecentre, hvor de stille aftentimer fyldes med blød musik, mens roen falder over både deltagere og beboere. 4) Randers Egnsteater holdt forpremiere på deres forestilling VÆK på Tirsdalens ældrecenter. 5) Hver søndag får Tirsdalen besøg af den lokale bogklub. Bogklubben har længe ledt efter et handicapvenligt lokale, da to af deltagerne sidder i kørestol. Nu har de fundet sig godt til rette i et mødelokale med god adgang og handicaptoilet, så bøger kan blive læst (op) og diskuteret af klub sammen med ældre.

Et tilsvarende eksempel på gaveøkonomi ser vi i Thy. Ejerforeningen Vorupør Klit har i samarbejde med Nationalpark Thy arrangeret, at borgerne gratis må fælde uønskede nåletræer i form af bjergfyr i nationalparken. ${ }^{\text {iv }}$ Der er to parter, eller gavegivere, der får gavn af projektet. Den ene part stiller træer til rådighed (gave) og de anvendes af borgere som juletræ, pynt i juledekorationen eller til vinterdække af haven. Den anden part, Naturstyrelsen, sparer udgifter og medarbejderressourcer forbundet med træfældning, da det er borgeren der yder indsatsen (gengave). Deri består gaveudvekslingen: Hver part får adgang til det, som de andre giver (gaver), ved selv af give (gengave). Som borgeren Pia Palm Nielsen fortæller: "Jeg synes da, det er alletiders, for man kan jo slå to fluer med et smæk, og det er jo økonomisk på alle måder, at man kan gå herud og fælde sit juletræ.”v

Randers og Thy er eksempler på gaveøkonomier. De udgør værdiskabende fællesskaber, der bygger på relationer, fordi hver part får adgang til det, som de andre giver (gaver), ved selv af give (gengave). Her har pengeøkonomiens adskillelsesmaskine ikke patent på velfærd og de deraf afledte organiserings-, og ledelsesprincipper. De har fundet en vej ud af velfærdsautomatismen. 
Samtidigt er det værd at notere sig, at hvis den samme værdi i begge tilfælde skulle skabes pengeøkonomisk, ville regnestykket ikke gå op. Hvad ældrecentrene angår, så ville deres driftsbudgetter ikke kunne rumme den betragtelige mængde ekstraansættelser, der skulle til for at matche samme mængde nærvær og aktiviteter. Og foreningerne ville ikke ud af egen lomme have råd til at leje hvert sit lokale til egne aktiviteter. Hvad angår initiativet i Thy, så er den åbenlyse besparelse allerede gjort op og værdien for borgeren er heller ikke til at tage fejl af. I begge tilfælde overstiger den gaveøkonomiske velfærdsværdi den pengeøkonomiske - for alle parter.

\section{Oversigt}

Men hvad er velfærdsværdi? Hvordan står pengeøkonomien nærmere bestemt i vejen for velfærd? Og hvordan overgår gaveøkonomiens velfærdsværdi pengeøkonomiens? Svarene på disse spørgsmål bliver opbygget gennem artiklens fire dele: For det første beskrives artiklens analysestrategi (del 1), dvs. med hvilke begreber sammenligningen mellem de to økonomier foretages. Dernæst foretages en teoretisk-principiel analyse af pengeøkonomiens og gaveøkonomiens velfærdspotentiale (del 2). Analysen afløses af flere eksemplariske cases, der på forskellig vis illustrerer gaveøkonomiens målelige velfærdsværdi efterfulgt af en overbliksmodel, der fordeler gaveøkonomierne henover akserne digital-fysisk og større-mindre (del 3). I den afsluttende konklusion sammenfattes bidraget i en diskussion af, hvordan gaveøkonomien udgør en vej til ny velfærdsværdi, og hvad de kommende udfordringer byder på.

\section{B. Analysestrategi}

Artiklen anvender en systemteoretisk inspireret analysestrategisk tilgang, der betoner iagttagelser af iagttagelser (Andersen, 2003). Mere præcist er der tale om iagttagelsen af de iagttagelser af velfærdsværdi, som de to økonomier stiller til rådighed og som gør det muligt at organisere og kommunikere om den.

Den metode som anvendes er funktionel metode (Knudsen, 2014). Knudsen understreger at funktionel metode gør det muligt at sammenligne det undersøgte fænomen (fx pengeøkonomi) med andre mulige alternativer, eller funktionelle ækvivalenter (fx gaveøkonomi) - en sammenligning, der i nærværende artikel giver distance til pengemediet, fordi det ses i lyset af dets alternativ, gaven. Når metoden stiller skarpt på funktioner, er det fordi begge medier udgør løsninger på den udfordring, der knytter sig til skabelsen af velfærd.

Analysestrategien beder om at gøre rede for, hvordan økonomiernes iagttagelser iagttages. I dette tilfælde sker det gennem fire begreber: form og medie (Andersen, 2019), program (Luhmann, 2000, kap 4; Thyssen, 2000) samt velfærdsværdi opgjort i form af hard value og social value (Thygesen \& Löfvall, 2020). Før sammenligningen mellem de to økonomier foretages, gennemgås de fire begreber. 


\section{Medie}

Penge er et medie, fordi det medierer udvekslingen mellem to eller flere parter. Det samme gælder gavemediet, som også medierer udvekslinger, omend på en anden måde.

Både penge og gave kan man kalde supermedier i den forstand at de ækvivalerer de Luhmanns begreb om symbolsk generaliserede medier (Luhmann, 2016, kap 2). I dette tilfælde fordi der i princippet, men også kun i princippet (!), kan sættes penge og pris på alt og alle selvom det ikke er alt og alle, der bliver penge og prissat. Det samme gælder gaven. Alt og alle kan i princippet, men kun i princippet (!), henregnes en gave. Man bidrager med det, man har, eller det man kan, selvom ikke alt, hvad man har og kan, gøres til bidrag.

\section{Form}

Hvert medie stiller en form til rådighed, som betyder, at den måde vi iagttager udvekslingen mellem parter på, ikke er tilfældig. Penge forudsætter evnen til at betale og udelukker derfor ikke-betalinger. Pengemediet stiller altså formen betale/ikke betale til rådighed (Luhmann, 1982). På et trin lavere niveau formgiver penge den økonomiske udveksling som en transaktion, hvor formen, der stilles til rådighed, er varer/penge eller, som vi var inde på indledningsvist, ydelse/penge (Boldyrev, 2013).

Gaven, derimod, er et andet medie, som stiller en anden form til rådighed. Formen er gave/gengave. Forholdet mellem gave og gengave består i forpligtelsen til at give, forpligtelsen til at modtage og forpligtelsen til gensidighed. Og det er en økonomisk udveksling, der skaber velfærdsværdi, på en måde, hvor hver part får adgang til det, som andre giver (gaver), ved selv af give (gengave). Som de gør det i Randers og Thy.

\section{Program}

Form-medie distinktionen bistås af program-begrebet. Det er det to grunde til. For det første fordi organisationsprogrammer giver adgang til iagttagelsen af organisationers egne formelle organiseringer. For det andet fordi de giver adgang til iagttagelsen af den programmerede og dermed forventede og efterfølgende registrerede velfærdsværdi, der følger med disse organiseringer.

Men hvad er programmer så?

Programmer er organiserede præmisser for beslutninger, der i sig selv er besluttede. Fx er det et beslutningspræmis i mange kommuner, at tildeling af ressourcer foregår i form af normeringer og at opgørelsen af velfærd vurderes i form af ydelsernes enhedsomkostninger. Til forskel herfra udgør et gaveprogram $\mathrm{fx}$ de forpligtelser ( $\mathrm{fx}$ retningslinjer og aftaler), der ligger til grund for 
organiseringen af velfærdsværdi, som vi så blandt de seks ældrecentre i Randers Kommune og i Thy Nationalpark.

\section{Velfærdsværdi som hard value og social value}

Hvad angår velfærdsværdi, skelnes der mellem to typer af værdi, der knytter sig til artiklens definition af velfærd. Som sådan er hard value og social value analysestrategiske begreber, men de er også ment som begreber, hvormed vi i det hele taget kan tale om velfærdsværdi i samfundet.

For at starte i velfærden, så forsøges automatismen mellem velfærd og ydelser fjernet. I stedet anvendes en anden definition af velfærd - at 'færdes vel' - som er bred nok til at lade velfærd dukke op relativt til to økonomier, frem for at forfalde til den pengeøkonomiske. Nu kan 'færdes vel' dække over så meget. Derfor er det vigtigt at nævne, at det er den vel-færden, som opbygges gennem forventninger i (de konstante justeringer af) den social samfundskontrakt mellem borger(e) og samfund (Thygesen \& Löfvall, 2020, kap. 1) - på alle niveauer af service i det offentlige.

Med henblik på at få et fast greb om værdi, skelnes der som sagt mellem hard value (den 'objektive' og udregnede værdi) og social value (den 'oplevede' og sociale værdi). Denne dobbelte bundlinje eller dobbelte velfærdsværdi svarer til, at den nuværende regering ønsker en 70 \% reduktion af CO2 udslippet inden 2030 (hard value), men samtidigt understreger, at det ikke må gå ud over den sociale bæredygtighed og oplevelsen af at være en del af fællesskabet eller flere af dem (social value).

Distinktionen mellem hard value og social value anvendes også inden for flere økonomiske discipliner. Inden for den klassiske økonomi, er det ikke ualmindeligt at fokusere på hard value, fx makroøkonomisk (BNP) eller mikroøkonomisk (consumer value), men også i samme takt at ignorere eller endda bevidst fraregne sociale faktorer og social value, for at få de økonomiske modeller til at gå op (Acemoglu, Laibson \& List, 2019). Inden for socio-økonomien forholder det sig omvendt, da dette forskningsfelt gør en dyd ud af at medtage det sociale og det økonomiske (fx Graeber, 2013). Især ser vi distinktionen i spil inden for de dele af feltet, hvor der arbejdes med at undersøge samfundsværdien af sociale økonomier eller flere økonomier (Eisenstein, 2011; Fukuyama, 1995; Putnam, 1995, 2000, 2004) samt inden for flere organisationsanalyser (Gabbay \& Leenders (Eds.), 2001; Hasle et al., 2010; Olesen et al., 2008; Vestergård, 2014).

Alt i alt er fordelen i denne analysestrategi dens høje generaliseringsniveau og evnen til at se skoven frem for hvert enkelt træ. Denne fordel indebærer imidlertid mindst to blinde pletter. For det første bypasser formelle programmer mange af de uformelle og uforlignelige initiativer, der opstår som gode bevægelser eller fungerer som værdifulde netværk og som ikke ualmindeligt bliver holdt sammen af gavestrømme. For det andet kan man med den iagttagelsesledende forskel (form/medie) 
ikke opgøre præcist, hvor meget pengeøkonomien dominerer over gaveøkonomien og ej heller i hvilket tempo nye gaveøkonomier spirer frem.

Når det så er sagt, så skal det ikke komme bag på nogen, at der er deciderede mørke sider ved begge økonomier. Pengeøkonomien bruges til bestikkelse, magtmisbrug og udnyttelse - selv i en offentlig kontekst. Og gaveøkonomien praktiseres i høj grad i kriminelle miljøer og uformelle økonomier, når den enes tjeneste er den andens værd - hvilket vi desværre heller ikke er ubekendte med i en offentlig kontekst ${ }^{\mathrm{vi}}$. Disse kritikker tages ikke op her, og melder sig derfor som en tredje blind plet. Derfor er det også værd at understrege, at det er de formelle programmer, der er politisk vedtagne og juridisk autoriserede, der gøres til genstand for iagttagelse.

\section{Empiri}

Eftersom det ikke er første gang, at der foretages en (kritisk) analyse af de to økonomier, referer artiklen frem for primær program-empiri til disse analyser af den danske offentlige sektor. Analyserne udgør en del af det socioøkonomiske forskningsfelt, og især anvendes dem, der sætter pengeøkonomien i spil over for gaveøkonomien (Thygesen og Löfvall, 2020; Graeber, 2013; Eisenstein, 2011) samt Fukuyama (1995) og Putnam (1995, 2000, 2004). Alle parter taler om pengeøkonomi over for ressourceudveksling og hvoraf sidstnævnte udgør den gaveøkonomiske udvekslingsform. Og endelig udgør de også den del af den offentlige institutionelle historie som beskæftiger sig med overgangen fra velfærd som et juridisk begreb (universalismen) til velfærd som et økonomisk begreb defineret ved Managementstaten og Konkurrencestaten (Pedersen, 2011; Pedersen, 2004). Til sidst anvendes case materiale som i programmatiske form udgør policy papers, formelle selvbeskrivelser samt flere af den kilder, som de henviser til.

\section{Pengeøkonomien og gaveøkonomien}

Efter den indledende analysestrategi bevæger artiklen sig over i den teoretisk-illustrativ analyse af pengeøkonomiens og gaveøkonomiens velfærdspotentiale. En smagsprøve blev allerede givet i indledningen og dermed også artiklens set up. Budskabet er, at pengeøkonomien nogle gange kan stå i vejen for velfærd (det første hovedbudskab) og at der findes et økonomisk alternativ til pengeøkonomien, gaveøkonomi, hvis velfærdspotentiale kan overgå pengeøkonomiens (det andet hovedbudskab).

\section{Penge og gaver som medie og form}

Penge og gaven er begge et medie for økonomiske udvekslinger, men hvert medie giver forskellig form til udvekslingerne og dermed skabelsen af værdi. 
Pengeøkonomiens form, når det gælder økonomiske transaktioner, er som nævnt vare/penge eller ydelse/penge ${ }^{\text {vii }}$.

Det kommer ikke bag på nogen, at New Public Management (NPM) har mimet denne form og at den stadig er levende under den nuværende Konkurrencestat. Det viser i særdeleshed den økonomiske retorik. Offentlige institutioner bliver benævnt 'virksomheder', service anses som 'ydelser', og borgere omtales som 'kunder'. Internt blandt kommuner er det heller ikke ualmindeligt at forvaltningerne bestiller leverancer og ydelser fra tværgående enheder som fx IT-, og systemenheder og som efter bestillingen udsender en faktura. Transaktionen kunne i princippet ligeså vel gælde enhver anden virksomhed, som solgte og fik betaling for ydelsen fra kunden.

Senere blev denne mikro-økonomiske drejning videreudviklet. Enhedsomkostninger for hver enkeltydelse blev indført som princip, og de steder hvor det kunne lade sig gøre, skulle tiltaget sikre bedst og billigst samt inkludere flere udbydere. I samme takt blev ydelserne deklareret for at fremme frit valg og borgere blev samtidigt iagttaget i form af opdelte målgrupper og nogle endda helt individualiserede i udmålingen af specifikke behov.

Selvom forskellige agilitetsprincipper vinder frem, følger størstedelen af den offentlige sektor alligevel den pengeøkonomiske organisering af velfærden udi adskilte funktioner og isolerede opgaver, hvorfor personaen Peter ender med otte handleplaner og 17 forskellige sagsbehandlere, eller flere. Faktisk bliver størstedelen af den offentlige service leveret af personer, opgaver og funktioner, som isoleres fra hinanden, eller bliver målt og evalueret, som om de var det. Og endelige tilfalder ydelserne gennem dette leverancesystem målgrupper og personer som Peter, som heller ikke forudsættes at have meget med hinanden at gøre.

Denne mikro-økonomiske drejning under NPM blev sluset ind i en makroøkonomisk vending, og hvis reform-, og lovgrundlag var dybt inspireret velfærdskommissionens arbejde (2003-2005) ${ }^{\text {viii. }}$. Denne tilbød blandt andet iagttagelsen af borgeren som opdelt i gennemsnitlig samfundsudgift (023 år og pensionsalderen) og gennemsnitlig samfundsindtægt (mellem 23 og pensionsalder). Derefter kunne man arbejde med at nedbringe udgiften og øge indtægten via forskellige reformer, som fx fremdriftsreformen, efterlønsreformen, dagpengereformen, aktiveringsreformen osv. Derfor er det heller ikke så mærkeligt, at "Staten er nødt til at gøre menneskeliv op i kroner og øre", som overskriften lød opinionsartiklen.

Sagt meget kort, så fulgte den mikroøkonomiske drejning med over i den makroøkonomiske. Og tilsammen udgør de et overgribende pengeøkonomisk rationale, der dækker distancen fra at iagttage hele samfundet som et velfærdssamfund til enkeltindivider som Peter. 
Gaveøkonomien tilbyder en anden form for økonomisk udveksling, som består i gave/gengave. Når parterne konverterer til gaveøkonomi, så består den i en anden form for økonomisk udveksling: at give, og selv får adgang til det, som andre giver. I det øjeblik er der på lige fod med pengeøkonomien tale om en udveksling, men værdien 'ret' og 'ejerskab' bliver konverteret til værdien 'gave' og 'adgang'. Ligesom de gjorde i Randers Kommune.

I pengeøkonomien er der altså tale om, at man bliver rig ved at eje. Med gaveøkonomien forholder

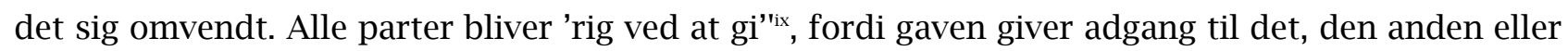
de andre også giver, og det gælder for alle bidragende parter.

Hverken medie eller form giver indsigt i økonomiernes værdiprincip. Blot at den form som hvert medie tilbyder, vender værdiprincippet om, fra at eje og kræve sin ret, til at give og skabe adgang til andre. Så spørgsmålet er, hvad gaveøkonomiens programmerede værdi er sammenlignet med pengeøkonomiens? Hermed bliver det teoretisk-principielt muligt, at præcisere hvad gaveøkonomiens velfærdspotentiale består af, velvidende at potentialet i praksis bliver højst forskelligt indløst og udfoldet.

\section{2. "Hard Value" som programmeret værdi}

Hard value udgør den målbare værdi. Anskuet som hard value indebærer pengeøkonomiens transaktioner to typer af adskillelse. Den første adskillelse består i, at den, der køber varen, som regel ikke har noget at gøre med den, der sælger varen. Vi går ind i transaktionen som adskilte, og vi går ud af transaktionen som adskilte. Denne adskillelse har også fået navnet nulsumsspil, fordi varen kun bytter plads med pengene. Der er med andre ord ikke skabt merværdi. Nulsum svarer i realiteten til de situationer, hvor velfærd via offentligt finansierede reformer bliver udmålt i indsatser, nedbrudt i ydelser og tildelt hver bruger, som har betalt for denne rettighed over skatter og afgifter. I Randers vil det svare til, at hver enkelt på plejehjemmet modtager en afmålt ydelse (fysisk aktivering i form af yoga og pilates) af en fysioterapeut, der er finansieret over plejehjemmets driftsbudget.

Den anden adskillelse består i, at den, der køber varen, adskilles fra de andre, der køber varen. Ingen behøver at have noget med hinanden at gøre. Denne nulsum svarer i det offentlige til, at de, der leverer ydelsen, ikke behøver at have noget med hinanden at gøre, ligesom de ældre, der modtager ydelsen, heller ikke behøver det.

At pengeøkonomiens adskillelsesmaskine er blevet dominerende, minder Peter os om. Som det fremgik i indledningen, så kan den programmerede værdi helt overse Peter's vel-færden, fordi den fokuserer på udførelse og måling af hver sin opgave eller ydelse. 
Det er primært gennem pengeøkonomiens nulsum, at vi forholder os økonomisk til velfærdens ydelseskatalog og ofte i forbindelse med effektiviseringer og justeringer heraf. Man kan gennem pengeøkonomien:

1) skrue op for velfærden ved at tilføre flere penge (positiv prioritering)

2) skrue ned for velfærden ved at trække penge tilbage (negativ prioritering)

3) skrue op for velfærden samtidigt med, at man skruer ned for pengene (effektivisering).

Man kan også inkludere effekter og målinger. I så fald er der ikke tale om ydelsens pris, men om:

4) ydelsens værdi for modtageren (evaluering).

Når 1+2+3+4 sættes i spil, bliver der ikke tilført merværdi. Hvis der fx prioriteres flere penge ét sted (1), må et andet sted bløde (2). Eller hvis man forsøger at skabe mere værdi begge steder, skal citronen presses yderligere (3). Eller man må forsøge at ramme mere plet ud fra modtagergruppens behov (4). Men i ingen af tilfældene bliver der flere citroner

$1+2+3+4$ lader sig hovedsageligt gøre på grund af pengeøkonomiens programmer, heriblandt budget og regnskab. Når disse tages i brug, kan man sætte pris på - dvs. udgifts- og omkostningsstyre den offentlige velfærdsindsats lige fra et måltid mad bragt ud af hjemmeplejen, tildeling af fysioterapi eller investeringer i Øresundsbroen. Og således kan man også skrue op eller ned for velfærden (1+2) eller effektivisere den (3). Man kan også sætte sig for at udmåle velfærdsværdi for den enkelte eller for udvalgte målgrupper eller opstille skræmmescenarier for udeblivelsen af den (4). På samme måde $(1+2+3+4)$ bliver der skruet op og ned for velfærdsindsatsen over for Peter samt effektiviseres og evalueres.

Til forskel fra pengeøkonomiens adskillelser bygger og opbygger gaveøkonomien på relationer. Relationer opstår, når den ene part giver og selv får adgang til det, som andre giver. Når der er tale om hard value, udgør gaveøkonomien til forskel fra pengeøkonomien et plussumsspil, fordi der skabes merværdi.

Gaveøkonomiens plussums-potentiale viste sig i praksis på ældreområdet i Randers. Det var den målbare service, som centrene nu kan levere uden at belaste driftsbudgettet. Set fra foreningerne side, så svarer den til de gode handicapvenlige lokaler, som gaveøkonomien giver adgang til, og som ellers ville have været omkostningstunge for hver forening at leje. Med en lommeregner i hånden, kan man forholdsvist nemt opstille et regnestykke for begge parter, der viser gaveøkonomiens besparelser samt hvilken velfærdsværdi de har skabt sammenlignet med pengeøkonomiens.

I princippet er plussum baseret på, at den ene part ejer noget, der er til nytte for den anden og vice versa. Dermed er grunden lagt til at indgå i gaveøkonomien. Omregnet i hard value betyder det, at 
en part med en udgift på fx $2.000 \mathrm{kr}$. for egen vare har adgang til en andens vare, som for eksemplets skyld også har kostet 2.000 kr. Her vinder begge i værdi, dvs. nytteværdi. Dvs. at den ene part for en udgift på $2.000 \mathrm{kr}$. kan skabe nytte for sig selv, som ellers ville have kostet $4.000 \mathrm{kr}$. Det samme gælder for den anden part. Deres samlede pengeudgift på $4.000 \mathrm{kr}$. er således $8.000 \mathrm{kr}$. værd i nytte. Her er der tale om et plussumsspil i den forstand, at den samlede sum stiger. I dette eksempel bliver antallet af varer fordoblet ved at konvertere det, man ejer (pengeøkonomi), til adgang (gaveøkonomi). Plussum udvikler sig endda til multiplicering, når en tredjepart, en fjerdepart ... deltager i gaveøkonomien. For nytteværdien multipliceres, for hver gang en ny part melder sig, og derfor kan man tale om gaveøkonomiens multipliceringseffekt ${ }^{\mathrm{xi}}$.

Allerede her er vi inde på en kolossal omvæltning af klassisk økonomi fordi antallet af citroner multipliceres. Det er denne principielle gaveøkonomiske værdimekanisme, som Randers benytter sig af. Og det er den mekanisme, som flere offentlige organisationer eksperimenterer med, når de engagerer sig i forskellige typer af ressourceudvekslinger såsom deleøkonomi, cirkulær økonomi og bytteøkonomi (Thygesen \& Löfvall, 2020, kap 9) samt flere former for samskabelser (Sørensen \& Torfing, 2018). De multiplicerer citroner.

Men der er endnu en forskel mellem pengeøkonomien og gaveøkonomien, hvad gælder hard value. Den består i, at det kun er penge (skatter og afgifter), der giver adgang til den økonomiske transaktion, men at så meget andet gælder som gave. En gave kan være noget materielt. Den kan også være immateriel, fx særlige kompetencer og viden, praktiske eller administrative færdigheder, kendskab til et stort netværk osv. Det gør gaveøkonomien langt mere inklusiv end pengeøkonomien, fordi der er plads til flere former for bidrag og derfor også til at løfte kæmpeopgaver som fx den manglende omsorg i vores ældrepleje. Det giver Randers en betragtelig fordel, da deres pleje nu ikke længere kun afhænger af driftsbudgettet, men også af gavebudgettet via andre (forenings)aktiviteter.

Det forbløffende er, at der allerede er sat tal på værdien, men i større omfang. Allerede i 1995 regnede økonomen Wilfred Dolfsma sig frem til, at halvdelen af alt, hvad der produceres i verden, er gaver ${ }^{\mathrm{xii}}$. Senere byggede to af verdens mest velansete forskere inden for feltet, Robert Putnam og Francis Fukuyama, deres undersøgelser på lignende principper. Fx peger Fukuyama på, at kun ca. $40 \%$ af et lands økonomiske vækst kan forklares pengeøkonomisk. De resterende $60 \%$ afhænger af

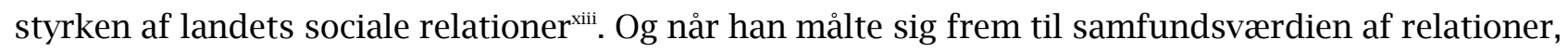
så er det, fordi han målte på tilfælde som i Randers på et aggregeret niveau.

Der er altså ikke tvivl om, at relationer er noget værd. Pengeøkonomiens nulsum kommer ikke i nærheden af gaveøkonomiens plussum. Det er det potentiale, som bliver aktiveret i Randers. Og det er det potentiale, mange andre indsatsområder i det offentlige kan drage nytte af. 


\section{3. "Social value" som programmeret værdi}

$\mathrm{Nu}$ kunne man stoppe her, for den værdi der lader sig beregne på en lommeregner, er den værdi, som vi ofte stiller os tilfreds med. Men gaveøkonomien producerer endnu en værdi oven i hard value, og som er social value.

I et pengeøkonomisk univers, som består af økonomiske transaktioner, er man adskilte fra hinanden. Til forskel herfra er social value integreret i gaveøkonomien ${ }^{\text {xiv }}$. Det skyldes forpligtelse. I en gaveøkonomisk terminologi forpligtelsen til at give (når du har modtaget), forpligtelsen til at modtage (når $\mathrm{du}$ har givet) og forpligtelsen til vedvarende at gengælde (reciprocitet). I gaveøkonomien er relationen mellem mennesker altså en relation båret af den forpligtelse, det indebærer at indgå i et værdiskabende fællesskab.

I modsætning til hard value er social value ikke blot en oplevelsesværdi, men også for mange livskvalitet, da de fleste af os kan ikke leve uden oplevelsen af at skabe noget sammen med andre. Vender vi tilbage til Randers, begynder parterne i gaveøkonomien utvivlsomt at lære hinanden at kende. I langt de fleste tilfælde opstår der et fællesskab ud af disse gavestrømme. Derfor bruger man også udtrykket 'at sætte pris på hinanden', fordi den anden eller de andre er noget værd for én selv. Derfor forpligter man sig.

Social value i form af forpligtende værdifællesskaber kan udvikle sig i mange retninger og antage mange former. Men som oftest bliver man glad i låget og lys i sindet, når man er en del af et fællesskab. Det bliver man som ældrecenter, når man sammen med foreningerne gør en forskel for andre og øger glæden. Det bliver man som forening, når man sammen med ældrecentrene skaber omsorg og trivsel for de ældre samtidigt med at dyrke ens passion. Og det bliver man som ældre, hvis man deltager og måske bidrager til glæden blandt besøgende børn fra en børnehave.

\section{4. "Hard value" \& "Social value"}

Pengeøkonomiens form opfordrer til at spørge: Hvad koster det (hard value)? Hvordan belaster det fx driftsbudgettet at tilbyde og drive et kombineret yoga- og pilateshold tre gange om ugen før aftensmaden? Den opfordrer også til at spørge: Hvad koster social value? Hvordan belaster det driftsbudgettet endnu mere at lave fælles arrangementer?

Groft sagt adskilles de to værdier - hard value og social value - i mindst to udgiftsposter, som var det adskilte aktiviteter. Og derfra kan udgifter, hyppighed og afmålte antal timer prioriteres, effektiviseres og evalueres efter 1+2+3+4-princippet - af hver sit ældrecenter med hver sit budget. Med gaveøkonomien forholder det sig anderledes. Ud af den vokser der en dobbelt bundlinje. Den består for det første i plussum (og eventuelle multipliceringseffekter), som producerer velfærd i form af hard value. Og den består for det andet i værdifællesskaber, som er en oplevelses og 
livsværdi, og som sådan udgør en 'social value'. Det er en dobbelt værdi i en og samme gaveøkonomiske operation. Det så vi i Randers, da hver bundlinje ikke krævede hver sin uafhængige indsats fordelt på hver sit driftsbudget blandt centrene eller blandt foreningerne. Eller som Pia Holm Nielsen fra Thy slog fast: "... man kan jo slå to fluer med et smæk". Den dobbelte værdi kan opsummeres meget kort:

$$
\text { Gaveøkonomi = plussum (hard value) + livskvalitet (social value). }
$$

Samlet set viser analysen den principielle velfærdsværdi indeholdt i gaveøkonomien. Der findes et økonomisk alternativ til pengeøkonomien i form af gaveøkonomi og tilmed er gaveøkonomien en økonomi, hvis velfærdspotentiale teoretisk og principielt overgår pengeøkonomiens. Nedenstående tabel formidler et overblik over de to økonomier:

\section{Gaveøkonomi = plussum (hard value) + livskvalitet (social value).}

Samlet set viser analysen den principielle velfærdsværdi indeholdt i gaveøkonomien. Der findes et økonomisk alternativ til pengeøkonomien i form af gaveøkonomi og tilmed er gaveøkonomien en økonomi, hvis velfærdspotentiale teoretisk og principielt overgår pengeøkonomiens. Nedenstående tabel formidler et overblik over de to økonomier:

\begin{tabular}{|l|l|l|}
\hline & Pengeøkonomi & Gaveøkonomi \\
\hline Medie & Penge & Gave \\
\hline Form & Transaktion & Gensidighed \\
\hline Program ('hard value') & Nulsum & Plussum \\
\hline Program ('social value') & Egeninteresse & Gensidig forpligtelse \\
\hline Hard value \& social value & Adskilte bundlinier & Dobbelt bundlinje \\
\hline
\end{tabular}

Tabel 1: Overblik over de to økonomier 1

\section{Eksemplariske cases og deres velfærdsværdi}

Et er den teoretisk-principielle værdi. Noget andet er, hvorvidt og hvordan værdien kommer til syne i praksis. Eller sagt på en anden måde, der er ingen værdi i at tale om værdi, hvis den ikke praktisk manifesterer sig - både nu og som en tro på fremtiden. Og Randers kan ikke ved siden af Thy stå alene som eksemplariske cases. 
Derfor gennemgås tre andre konkrete cases, der ligeledes er eksemplariske. De følges op af tre supplerende, for at vise spændvidden af initiativer. Her forstået som fysiske og digitale gaveøkonomier samt som større og mindre gaveøkonomier.

\section{Samsø Energiakademi og Aarhus Kulturby, 2017}

Et af de steder som har skabt uhørt velfærdsværdi med gaveøkonomisk organisering, er Samsø. Og grunden er den samme: Fordi det kan betale sig, sætter man også pris på den anden. Som den første $ø$ i verden er Samsø 100 pct. selvforsynende med alternativ energi. Ude i verden bliver Samsø derfor også omtalt som et grønt mirakel.

Indledningsvist forsøgte man at igangsætte omstillingen ud fra den pengeøkonomiske adskillelsesmaskine - først en drivende teknisk forvaltning, dernæst tekniske og økonomiske beregninger af hver opgave og til sidst lokalplanerne i høring. Projektet blev en dundrende fiasko, da de fleste lokale interessenter ikke kunne se værdien i at være med.

Senere gik man anderledes til værks og etablerede Energiakademiet, der skulle fungere som netværkscenter. Eller, i teoretisk forstand, en gaveøkonomisk platform. Bønder, håndværkere, institutioner, færgeselskab og vidensinstitutioner blev koblet sammen i nyskabende samarbejdsprojekter om sol, vind, varme og biogas, fordi det kunne betale sig for hver enkelt gavegiver. I Energiakademiet kaldes det for community power.

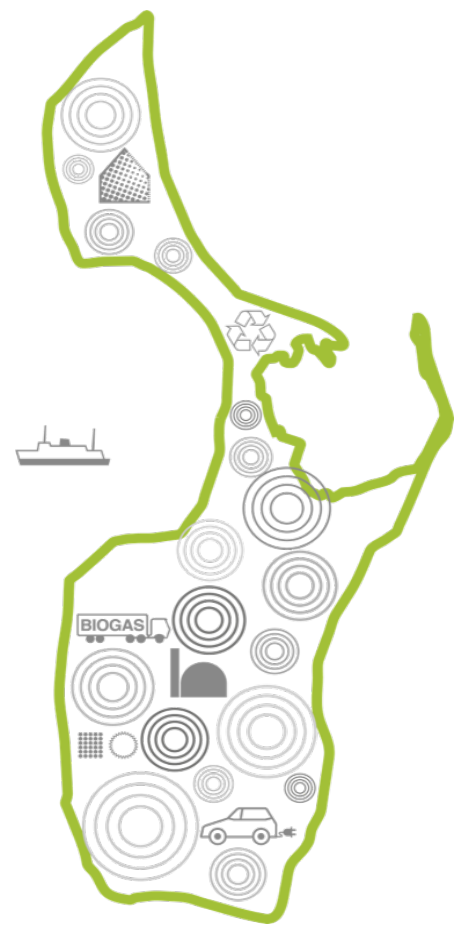

Som illustrationen viser, finder Samsøs grønne gaveøkonomi (cirkler) sted flere steder og på flere niveauer.

Blandt nye initiativer er det planen at opføre et biogasanlæg, som omdanner organisk affald, for eksempel halm fra markerne og husholdningsaffald, til byvarme og biogas til Samsøfærgen.

Den lille gavestrøm består i, at organisk affald tilføres biogasanlægget (gave), mens restaffaldet tilbageføres og gøder markerne (gengave). Denne gavestrøm producerer grøn energi og sparer penge for landmændene på øen. Den store gavestrøm består i, at det, som naturen giver (gave), føres tilbage til naturen som rene ressourcer (gengave). Disse gavecirkler giver god samvittighed, god ressourceøkonomi og grønne tal på bundlinjen. 
I dag kan Samsø registrere:

- At ca. 5.000 forskere, virksomheder, politikere, journalister, studerende osv. hvert år besøger øen.

- At Energiakademiets måde at organisere den grønne omstilling er blevet et benchmark for nationer som Tyskland, Japan, Holland.

- At øen i dag har befolkningstilvækst.

Supplerende kan det nævnes, at vejen til Aarhus kåring til Europæisk Kulturhovedstad, 2017, ligeledes gik hen over en gaveøkonomisk organisering. Ligesom det var tilfældet på Samsø, var det ikke i sidste ende Kommunen, der organiserede processen, dvs. planlagde og finansierede den. I stedet blev projektet drevet af Fonden Aarhus 2017, som var i stand til at samle partnere i ressourceudvekslinger, der skabte øget værdi for de involverede og for Aarhus by samt i regionen generelt.

I 2008 begyndte processen. Det var en proces, som tusindvis af borgere deltog i mellem 2008 og 2010. Samtidigt arbejde fonden på andre niveauer, på tværs af alle sektorer og har bragt offentlige myndigheder, kulturinstitutioner og virksomheder sammen. Det langsigtede perspektiv i at investere i kultur overgik langt tidligere resultater. Derfor indgår Kulturby Aarhus også i en række internationale netværk såvel som med tidligere og kommende europæiske kulturhovedstæder, fx Nordic City Network, Similar Cities-netværket og Eurocities Network.

Opgjort i hard value, så overgår Samsø's dokumenterede reduktion af CO2 andre lignende initiativer verdenen over. Og hvad interessen for Kulturby Aarhus angår, så har byen stadig den glædelige udfordring, at den ikke er i stand til at huse antallet af nysgerrige gæster. Opgjort i social value så er de fleste af de tusindvis af borgere, der har medvirket til at gøre Aarhus til kulturby, uden tvivl haft en god oplevelse af fællesskab. For Samsø's vedkommende har omstillingen ikke været one-off events, men er stadig en løbende og ambitiøs deltagerproces, som også betyder, at de fleste på øen færdes vel.

\section{Pil-IT og Kildeindtastningsprojektet}

Københavns Stadsarkiv stod over for deres livs udfordring i begyndelsen af 00'erne. 1,2 mio. registerkort skulle digitaliseres.

Ud fra gaveøkonomiske principper lykkedes det Stadsarkivet at mobilisere arkivets brugere - private og professionelle slægtsforskere, foreninger, forskningsinstitutioner - til at digitalisere registerkortene. Projektet hed Pol-IT. Brugerne indså hurtigt, at jo mere de indtastede (en gave til fællesskabet), desto flere kort kunne de selv tilgå i den fælles database, som blev opbygget af Stadsarkivet (gengaven fra fællesskabet). Projektet blev en kæmpe succes, fordi værdien var forrygende for alle parter: 
- Digitaliseringen af registerkort blev løst på 7 år. Skulle arkivets medarbejdere selv have stået for digitaliseringen ved siden af deres øvrige opgaver, ville opgaven have taget 100 år.

- Udgiften var beregnet til ca. 50 mio. kr. Opgaven blev løst med et internt årsværk over de 7 år.

- Antallet af arkivbrugere blev forøget 50 gange. Det skyldes den digitale adgang til arkivalierne.

Men en ting er at få mere ud af det, som organisationen har i forvejen. Den virkelige værdiforøgelse skal måles på nytteværdien. Digitaliseringen af registerkortene har øget deres anvendelighed i social-historisk og demografisk forskning. Men endnu mere afgørende er betydningen for forskere fra sundhedssektoren. De har med arkivets digitalisering langt bedre mulighed for at kortlægge mønstre og årsager til arvelige og epidemiske sygdomme som COVID19 - og dermed for at udvikle ny viden om sundhedsfremmende og sygdomsreducerende tiltag.

Supplerende kan nævnes kildeindtastningsprojektet, som blev etableret i 1992 som et samarbejde mellem Dansk Data Arkiv under Rigsarkivet og DIS-Danmark. ${ }^{\mathrm{xv}}$ Projektet lignede de første år Stadsarkivets opbygningen af egen platform. Men projekt kom på lige fod med Pol-IT i medvind, og flere aktører og ressourcer kom til og hvirvlede andre digitaliseringsprojekter med sig. I løbet af 25 år har en større gruppe af deltagere i gaveøkonomien indtastet 19,5 mio. oplysninger fra danske folketællinger i den åbne digitale platform www.ddd.dda.dk. I en tid, der er præget af både besparelser og stigende konkurrence om borgernes opmærksomhed og interesse, havde Rigsarkivet allerede i 2016 næsten en million besøgende samt forespørgsler fra både ind- og udland. De mange brugere dækker borgere, der dyrker slægtshistorie, lokalhistorikere, forskere fra især samfunds- og sundhedsvidenskaberne, journalister, statslige og kommunale myndigheder m.fl. Hvert år bistår Rigsarkivet borgere, virksomheder og myndigheder med at få løst komplicerede arvesager, dokumentere ejendomsforhold, skaffe dokumentation for skilsmisse, vielse, adoption eller statsborgerskab, ligesom det også hjælper borgerne med at fremskaffe $f x$ attester og

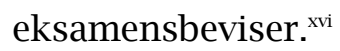

Tallene taler for sig selv og fordi det er Stadsarkivet og Dansk Data Arkiv, der har gennemført initiativerne, så er værdien opgjort i hard value gennemdokumenteret. Hvad angår social value, har især Stadsarkivet oprettet fysiske arrangementer og digitale communities, hvor de forskellige interesser kan mødes og udveksle viden. Alene fordi mange deltagere stortrives i disse fællesskaber.

\section{Tradano og "Politi"}

Tradano er et digitalt loppemarked. Da produktionschef (CPO) og medstifter Martin Suhr hørte, at en hjemløs døde af kulde i København, blev ideen født. Holdet bag Tradono gik i gang med at stable 
en gaveøkonomi på benene, hvis velfærdsværdi bestod i at hjælpe de mange hjemløse i København gennem vinteren. Det skulle ske gennem donationer af tøj. Gaveøkonomien indbefattede tre gavegivere. Tradano stillede deres digitale platform til rådighed, og hvor folk, der gerne ville donere tøj, kunne registrere sig (gave). ${ }^{\text {vii }}$ Samkørselstjenesten GoMore bidrog med biler og med udbringningen af tøj til herbergerne (gave). Og Københavns Kommune bidrog med viden og formidling af kontaktinformation om de offentligt støttede væresteder i København (gave). Gaveøkonomien var nu skudt i gang, og parterne havde skabt adgang til hinanden. Om aftenen den 25. februar 2016 nåede GoMore rundt til over 80 hjemløse i Københavnsområdet. I vinteren 2016 var der derfor ikke mange, der frøs. Gengaven for de tre parter bestod i den værdi, de høstede gennem engagementet:

- Københavns Kommune kunne med en minimal indsats levere en akut indsats over for de hjemløse. Hvis Kommunen selv skulle finansiere, ikke blot indkøb af varmt tøj til ca. 80 hjemløse, men også udbringning med lønninger til mandskab og evt. leje af biler, ville udgiften i driftsbudgetterne vokse betragteligt. Formentlig så betragteligt, at det ikke blev gjort, og at de hjemløse som konsekvens deraf ville fryse forfærdeligt i vinterkulden.

- Go-More bidrog i den ånd, den er stiftet, nemlig som samkørsel, og fik boostet deres image ganske betragteligt som samkørselstjeneste.

- Tradono forøgede antallet af medlemmer på egen platform, når folk registrerede sig.

Alle parter blev med andre ord 'rig ved at gi", fordi de indgik i en digital gaveøkonomi. Projektet blev så stor en succes, at dette triumvirat gentog indsatsen flere år frem, ikke mindst fordi der også er værdi i at dele en god dag sammen. Derfor blev GoMore og Tradano også enige om at skalere projektet i samarbejde med andre kommuner i landet. Nu er initiativet landsdækkende. ${ }^{\text {xiii }}$

Supplerende kan nævnes en anden digital platform og denne gang med Politiet som primus motor. At skabe tryghed er en stor del af politiets arbejde. Dansk politi's app, 'Politi', er bygget op omkring et gaveøkonomisk princip, hvor brugerne er involverede - i modsætning til Tradono's initiativ. App'en tilbyder muligheden for at give et digitalt og anonymt tip til sit lokale politi (gave). Tippene fører til, at politiet leverer en mere effektiv indsats og i sidste ende et tryggere lokalområde (gengave). I 2018, fire år efter lanceringen, havde 170.000 downloadet app'en, og især Nordjyllands, Østjyllands, og Nordsjællands politi har opnået nævneværdige resultater med det ${ }^{\mathrm{xix}}$. Politiet har registreret over 1400 tip om året. Oven i er der 4-500 brugere om dagen, der selv tjekker et cykelstelnummer. Initiativet har modtaget fire stjerner i bedømmelsen.

Hvis vi vender tilbage til velfærdsværdien opgjort som hard value og social value, så er er Tradano og Politi mindre initiativer målt op i mod de Samsø og Aarhus samt Stadsarkivet i København og 
Thygesen / Gaveøkonomi - en vej til ny velfærdsværdi

vores nationale Dansk Data Arkiv. Derfor er hard value og social value også mindre, men ikke relativt til indsatsen. Det er ift hard value initiativer, der med få midler og en mindre organisationsindsats, har betydet at de hjemløse kunne færdes-vel i kulden, og at kriminalitetsindsatsen har kunnet forbedres. Mens social value ikke kan siges at være den dominerende i 'Politi'-initiativet, så fremgår Tradano's initiativ som en skelsættende begivenhed for de medvirkende. 


\section{Variation og bredde}

Alle de nævnte cases er listet i nedenstående graf, som også tæller projekt 'lån et lokale' blandt ældrecentrene i Randers Kommune og initiativet bag træfældning i Thy Nationalpark.

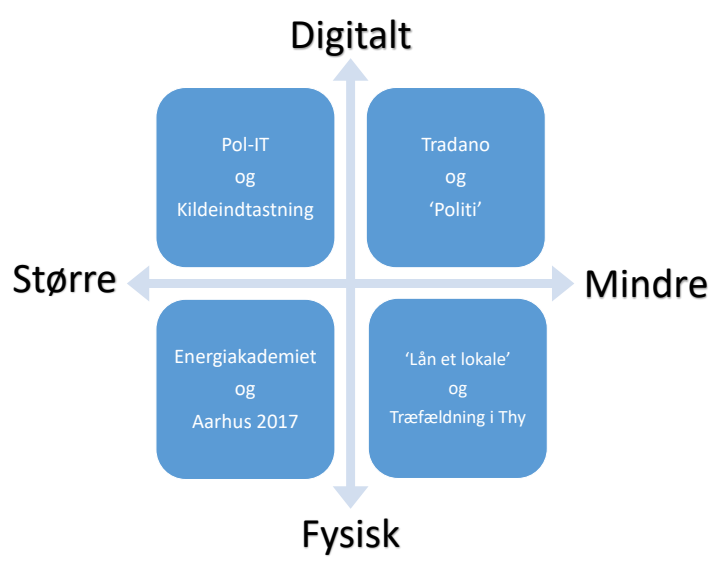

Figur 1: Gaveøkonomi variation og bredde 1

De otte cases placering i grafen viser spændvidden af gaveøkonomier i variation og bredde. Variationen i form af digitale eller fysiske (den lodrette akse) og bredden i form af størrelser (den vandrette akse).

Grafen er bevægelig og langt fra definitiv, hvilket understreger to forhold. For det første at gaveøkonomier ofte bevæger sig fra små til store projekter, al den stund at de har succes og i denne proces også kan bevæge sig mod at blive mere digitale. Gaveøkonomien i 'Lån et lokale' blandt ældrecentrene i Randers startede fx gennem nogle få kontakter, men voksede sig større og blev dermed en tand mere digitale. For det andet at de fleste fysiske gaveøkonomier i et vist omfang også er digitale, og at digitale gaveøkonomier ikke udelukker fysisk tilstedeværelse. Gaveøkonomien i Tradano var fx kun lykkedes gennem en kombination af fysiske møder mellem de tre parter og fysisk udbringning, selvom organiseringen skete på Tradano's digitale platform.

\section{E. Konklusion}

Artiklen har bidraget med et teoretisk-illustrativt bud på, hvordan gaveøkonomier kan bidrage væsentligt til vores velfærd i betydningen at 'færdes vel'.

Det første hovedbudskab er, at pengeøkonomien er en dominerende rationalitet, der endda kan stå i vejen for vores vel-færden. Er det så pengeøkonomien, der skal bekæmpes? Nej! Det er den 
blindhed, der naturligt følger med dens dominerende rationale, og hvorunder vores iagttagelse af dens kontraeffekt har svære kår. At Peter saves over i hobetal, er stadig et faktum.

Det andet hovedbudskab er, at pengeøkonomiens rationale er ikke det eneste rationale, der fører til, at vi færdes vel. Der findes en vej ud af den pengeøkonomiske automatisme, som består i gaveøkonomien. Denne økonomi producerer til forskel fra pengeøkonomien velfærdsværdi gennem relationer og ikke adskillelse og potentialet overgår pengeøkonomiens.

At potentialet over pengeøkonomiens var en teoretisk og principiel konklusion, men blev illustreret gennem otte eksemplariske cases fordelt henover to akser - fysisk-digital og større-mindre. Pointen er, at gaveøkonomien også udgør en praktisk organisering af vores vel-færden og at den allerede fremviser et målbart og dokumenteret potentiale.

Gaveøkonomiens potentiale er et potentiale, der skal ses i lyset af den underskov af nye organiseringer og værdifællesskaber, der vokser frem og som går under betegnelser som deleøkonomi, kollaborativ økonomi, cirkulær økonomi og til dels samskabelse. Hvad der kendetegner dem alle, er, at de skaber værdi gennem relationer og specielt de relationer, der bygger på ressourceudvekslinger i form af gavegivning. Potentialet skal også ses i lyset af en historisk underskov i form af lokale demokratier, foreningsaktiviteter og (andels-)bevægelser og dermed på en traditionsbestemt og velkendt gaveøkonomi der kan genaktualiseres og udvikles i nye (digitale) former.

Til sammen udgør de to hovedbudskaber ambitionen om at skabe og kvalificere en ny bølge af good Governance og offentlige ledere, der som mål eftersøger velfærdsværdi eller som Mark Moore udtrykker det: 'Public value'.

Men hvad bliver udfordringen så? Spørgsmålet skal ses i lyset af, at pengeøkonomien er den overvejende økonomi, hvormed vores moderne velfærdsstat gennem de sidste 25 år er opbygget. Det betyder at:

- Vi skal bekæmpe blindhed og ikke pengerationalitet. Det indebærer at vi fortæller os selv, at pengeøkonomien også har stærke slagsider og at det modsatte af pengeøkonomi ikke er 'ikke-økonomi', men gaveøkonomi.

- Vi skal bekæmpe sikkerhed og i stedet turde løbe en risiko. Den består i, at vi på et meget konkret plan starter gaveøkonomiske initiativer, der hvor de giver mening, og er opmærksom på den velfærdsværdi, som de skaber. 
Vi skal, i en lettere omskrivning af et gammelt ordsprog, ride på to (økonomiske) heste. Og heri består samfundsudfordringen.

Det indebærer en politisk udfordring, al den stund at gaveøkonomiens store potentiale bør anerkendes og stimuleres - selv af Finansministeriet og det stigende antal økonomiske rådgivere i andre ministerier bør gaveøkonomien tildeles legitimitet.

Det indebærer en ledelsesopgave, for det er her de konkrete initiativer skal udspringe og de konkrete erfaringer drages. Megen ledelse handler om adskillelse, om at svinge en ragekniv, der adskiller funktioner, ansvar og opgaver samt opdeler velfærden i ydelser. At opbygge, vedligeholde og videreudvikle gaveøkonomiske organiseringer indebærer modet til at erstatte disse adskillelser med gaveøkonomiske relationer.

Det indebærer en medarbejderopgave, fordi de aldrig må glemme, at der med usynligt blæk på deres ansættelseskontrakt står, at de sammen med gode ledere er sat i verden til at sørge for at borgere færdes vel. Og for så vidt at det ikke er tilfældet, også er ansat til at råbe op.

Det indebærer slutteligt en forskningsopgave, for det er her, gaveøkonomiens voldsomme potentiale teoretisk kan udvikles, empirisk undersøges, og endda udsættes for berettiget kritik og evaluering. Og i takt hermed er det en også undervisningsopgave, bl.a. fordi efteruddannelsessektoren er et outlet for forskningen og en brobygning til praksis og offentlige ledere, der kan sætte gaveøkonomien i lokal kontekst og starte egne initiativer - ligesom de gjorde i Randers og Thy. 


\section{Referencer}

Acemoglu, D. Laibson, D. \& List. J. (2019). Economics, Pearson.

Andersen, N. Å. (2019). Form og medie: Intermedialitet og analysestrategi på tvars af perceptionsmedier, kommunikationsmedier, biomedier og fysiske medier. Nyt fra Samfundsvidenskaberne. https://doi.org/10.7146/aul.177.137

Andersen, N. Å. (2003). Discursive Analytical Strategies: Understanding Foucault, Koselleck, Laclau, Luhmann. Policy Press. https://doi.org/10.2307/j.ctt1t898nd

Boldyrev, I. A. (2013). Economy as a Social System: N iklas L uhmann's Contribution and its Significance for Economics. American Journal of Economics and Sociology, 72(2), 265-292. https://doi.org/10.1111/ajes.12013

Bourdieu P (1996). The work of time. In: Komter AE (ed) The Gift: An Interdisciplinary Perspective. Amsterdam: Amsterdam University Press, pp. 135-147.

Bourdieu P (1979). Symbolic power. Critique of Anthropology 4(13-14): 77-85.

B., Malte (2. december 2019). Overblik: Her er hovedpunkterne i aftalen om finansloven, Altinget. (https://www.altinget.dk/artikel/her-er-hovedpunkterne-i-aftalen-om-finansloven)

Derrida J (1997). The time of the king. In: Schrift AD (eds) The Logic of the Gift: Toward an Ethic of Generosity. New York, NY: Routledge, pp. 121-147.

Eisenstein C (2011). Sacred Economics: Money, Gift, and Society in the Age of Transition.Berkeley, CA: North Atlantic Books.

Ejersbo, N., \& Greve, C. (2014). Moderniseringen af den offentlige sektor. Akademisk Forlag.

Fonden Aarhus (2017): Welcome Future, Hele Vejen Print: We Produce ISBN: 978-87-999627-6-1. Fremtidens velfærd - vores valg (2003-2005): Rapport fra Velfærdskommissionen på Finansministeriets hjemmeside.

Fukuyama F (1995). Trust: The Social Virtues and the Creation of Prosperity (No. D10 301 c. 1/c. 2). New York: Free Press Paperbacks.

Gabbay, S. M., \& Leenders, R. T. A. (Eds.). (2001). Social capital of organizations. Emerald Group Publishing Limited.

Graeber D (2013). It is value that brings universes into being. HAU: Journal of Ethnographic Theory 3(2): 219-243. https://doi.org/10.14318/hau3.2.012

Hasle, P., Thoft, E., \& Olesen, K. G. (2010). Ledelse med social kapital. 
Herby, J. (2/6/2020): "Jonas Herby: Staten er nødt til at gøre menneskeliv op i kroner og øre", Altinget.

Hermansen, S., \& Nørretranders, T. (2013). Fælledskab= fælled+ fællesskab. Samsø Energiakademi, Samsø.

Informationen (16-03-2020): Det er alt for tidligt at afgøre, om kampen mod corona er pengene værd.

Knudsen, M. (2014). Metodisk overrasket: Om systemteori og funktionel metode (pp. 19-40). Nyt fra Samfundsvidenskaberne.

Luhmann, N. (2016). Samfundets samfund. Hans Reitzel.

Luhmann, N. (2000). Sociale systemer: grundrids til en almen teori. Hans Reitzel. https://doi.org/10.7146/mediekultur.v10i22.1017

Luhmann, N. (1982). The economy as a social system. The differentiation of society, 190-225.

Moore, M. H. (1995). Creating public value: Strategic management in government. Harvard university press.

Olesen, K. G., Thoft, E., Hasle, P., \& Kristensen, T. S. (2008). Virksomhedens sociale kapital: Hvidbog.

Pedersen, O. K. (2011). Konkurrencestaten. Hans Reitzels Forlag.

Pedersen, D. (2004). Offentlig ledelse i managementstaten. København, Samfundslitteratur

Putnam RD (ed) (2004). Democracies in Flux: The Evolution of Social Capital in Contemporary Society. New York: Oxford University Press.

Putnam, R. (2001). Social capital: Measurement and consequences. Canadian Journal of Policy Research, 2(1), 41-51; Putnam, R.D.

Putnam RD (2000). Bowling alone: America's declining social capital. In: Crothers L and Lockhart C (eds) Culture and Politics. New York: Palgrave Macmillan, pp. 223-234. https://doi.org/10.1007/978-1-349-62397-6_12

Putnam RD (1995) Tuning in, tuning out: The strange disappearance of social capital in America. PS: Political Science and Politics 28(4): 664-683. https://doi.org/10.2307/420517

Randers Kommune (3/7/2017): Der kom mere liv på ældrecentrene”, Randers kommune (https://www.randers.dk/nyhedsarkiv/der-kom-mere-liv-paa-aeldrecentrene/)

Rigsarkivet (2017): Rigsarkivets årsberetning, 2017, Rigsarkivet. 
Sørensen, E., \& Torfing, J. (2018). Den offentlige sektor som en arena for samskabelse. In Ledelse og samskabelse $i$ den offentlige sektor(pp. 30-61). Dansk Psykologisk Forlag. https://doi.org/10.7146/politica.v26i3.67855

Thygesen, N. (2019). The gift economy and the development of sustainability. Local Economy, 34(6), 493-509. https://doi.org/10.1177/0269094219882261

Thygesen, N. \& Löfvall, S. (2020). Gaveøkonomi - ny vej til bedre velfoerd, Gyldendal Public.

Thyssen, O. (2000). Luhmann og ledelse: om Niklas Luhmanns Organisation und Entscheidung. Department of Management, Politics and Philosophy.

Tække, J., \& Paulsen, M. (2008). Luhmann og organisation. In Luhmann og organisation (pp. 11-39). Unge Pædagoger. https://doi.org/10.7146/mediekultur.v26i49.2985

Vestergård, E. (2014). Social Kapital i organisationer: Ledelse, kommunikation og samarbejde. In Social Kapital I Organisationer.

\footnotetext{
${ }^{i}$ Ugebrevet Mandag Morgen, d. 22 jan., 2018.

ii Analysen foretaget af Deloitte fremgik i Ugebrevet Mandag Morgen, d. 22 jan., 2018.

iii https://www.randers.dk/nyhedsarkiv/der-kom-mere-liv-paa-aeldrecentrene/ (set d. 8/9-2020).

${ }^{i v}$ Fæld dit eget Nationalpark-juletræ. Limfjord Update, 7. december 2017.

${ }^{v}$ Nationalpark Thy tilbyder gratis juletræer: Du skal bare hente det selv. TV2 Nord, 1. december 2018. Se https://www.tv2nord.dk/artikel/nationalpark-thy-tilbyder-gratisjuletraeerdu-skal-bare-hente-det-selv.

${ }^{\mathrm{v}}$ En uddybende diskussion af gaveøkonomiens bagsider foretages blandt andet af Thygesen \& Löfvall (2020) i kap 11.

vii Niklas Luhmann skelner mellem den af økonomiens form, der muliggør systemdannelse, og den er for økonomiens vedkommende betale/ikke betale. På et mere konkret niveau nævner Luhmann flere typer økonomier, heriblandt dem, der beror på økonomiske transaktioner. På dette niveau omtaler han også formen for transaktioner for vare/penge, dvs. varer eller 'goods' i bred forstand og penge som (et blandt mange) betalingsmidler. Se også Boldyrev, 2013.

viii Fremtidens velfærd - vores valg (2003-2005): Rapport fra Velfærdskommissionen på Finansministeriets hjemmeside.

ix Gaveøkonomien omtales i Nørretranders (2003) og Thygesen (2013; 2008)

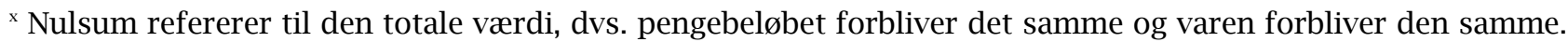
Det, nulsum ikke regner med, er consumer value for den ene parts vedkommende og fortjenesten ved salget for den anden parts vedkommende. For en uddybende diskussion heraf, se gerne Acemoglu, Laibson og List (2019).

xi Dette økonomiske princip, som her bliver kaldt for gaveøkonomi, gør sig gældende i forskellige varianter inden for forskellige forskningsfelter og er blevet udviklet teoretisk, studeret gennem analyser og dokumenteret praktisk. Det gælder social kapital-forskningen, som betoner, at relationer er noget værd; forskningen inden for videnøkonomi, der betoner, hvordan udvekslingen af en ide fra en part til en anden og vice versa betyder, at hver part efterfølgende har to ideer, dvs. fire i alt og så fremdeles; netværk og netværksøkonomien, som betoner, hvordan netværksknudepunkter skaber lignende multipliceringseffekter. Inden for den private sektor er princippet på fremmarch som en eksplosiv forretningsmodel under navne som sharing economy, collaborativ economy og til en vis grad crowd sourcing. Det sidste kan man have mange meninger om, men det understreger den kolossale værdi i gavegivningen, og mens det private skummer overskuddet og kan beskytte deres organiseringsprincipper og især softwaren mod konkurrenter, er det samme
} 
ikke muligt i det offentlige. Her gælder ingen eksklusivret. Her skal der ikke skummes overskud. Og her er der ingen aktionærer, der skal tilfredsstilles. Her tilfalder værdien (skatte-)borgeren.

xii Dette opsigtsvækkende resultat omtales og bringes videre ind i en gaveøkonomisk konktekst af Tor Nørretranders i Det Generøse Menneske (2003)

xiii Fukuyama, F. (1995). Trust: The social virtues and the creation of prosperity. Free Press Paperbacks; Putnam, R. (2001). Social capital: Measurement and consequences. Canadian Journal of Policy Research, 2(1), 41-51; Putnam, R.D. (2000). Bowling alone: America's declining social capital. I Culture and politics, s. 223-234. Palgrave Macmillan, New York.

xiv Gaveøkonomi stammer fra studier foretaget af antropologer og sociologer (Derrida, 1997, Bourdieu, 1979; Mauss, 1925), som har været interesserede i at afdække social sammenhængskraft, og den er senere taget op af politologien (Fukuyama, 1995, Putnam, 2001, 2000, 1995) og dele af økonomien (Eisenstein, 2011; Graeber, 2013). Til trods for diversitet inden for det socioøkonomiske forskningsfelt synes de forskellige discipliner helt overordnet, men også meget præcist, at dele den opfattelse af gaveøkonomien, at den udgør social value, og at den i høj grad ligger til grund for værdien i vores civilsamfund.

${ }^{x v}$ For en nærmere beskrivelse af projektets historier, se Christiansen, S.-E. (2000). KildeIndtastningsProjektet og folketællingen 1801. Personalhistorisk Tidsskrift, 2, s. 257-65, og Clausen, N. F. (2001). Kildeindtastningsprojektet. Metode \& Data, DDA Nyt, 84(1). Se også Indtastningsprojektet KIP fylder 25 år. Rigsarkivet, 22. september 2017 (www.sa.dk/da/news/kildeindtastningsprojektet-fylder-25-aar/).

xvi Rigsarkivets årsberetning 2017.

xvii Tradono begyndte som en Facebook-gruppe og udvidede derefter med en app. I dag

findes Tradono udelukkende på brugernes smartphones.

xvii Varmt tøj til hjemløse. Tv2 Lorry, 25. februar 2016.

xix Thygesen, N. \& Löfvall, S. (2020). Kap 10 i Gaveøkonomi: Ny vej til bedre velfard, Indledning. Gyldendal Business; Thygesen, N. (2019). The gift economy and the development of sustainability. Local Economy, 34(6), 493-509. 